at the Medical College of Virginia have successfully tested the detoxification of these workers and continue to study the human body's enzymatic conversion of Kepone.

\section{Toxic Substances}

The enactment and enforcement of regulations to protect Virginia's water resources and public health from toxic and hazardous substances are now being closely monitored by the Virginia office of the Environmental Defense Fund. Start-up funds from the Endowment have enabled EDF to provide scientific and legal assistance to government agencies and citizens on issues related to ground-water and surface-water quality and the disposal of hazardous wastes.

Initial funding from the Virginia Environmental Endowment has also enabled the Virginia State Chamber of Commerce to establish the Virginia Industrial Waste Exchange, a referral service for buyers and sellers of the byproducts of manufacturing processes.

\section{Environmental Laws}

In the priority area of environmental law, a comprehensive analysis of Virginia's water-resource needs and legal alternatives for water allocation has been one of the Endowment's most important grant programmes. This study by Virginia Polytechnic Institute and State University is the basis for State legislative debate on water rights and transfers.

The Endowment worked extensively with the national Environmental Law Institute to develop a model State statute for compensation, for personal injury or illness, of victims of pollution by toxic substances. The Endowment is now collaborating with the State Government and the mining industry to develop effective regulations for the mining and milling of uranium, which has recently been discovered in Virginia.

\section{Community Improvement}

The Endowment's interest in community environmental improvement has taken the form of support to a variety of projects which build on local initiative and cooperation. Just a few of these programmes include educational training on aquatic ecology, toxic substances, and water quality; on emergency procedures for local water-supply contamination; on preservation and use of natural lands, parks, and trails; and on training for medical personnel to reduce patient-exposure to $\mathrm{X}$-rays.

\section{Environmental Mediation}

Probably the Virginia Environmental Endowment's most promising and potentially productive grant programme is the Institute for Environmental Negotiation, which opened in 1981 at the University of Virginia, Charlottesville. The Institute is one of five centres in the United States which provides neutral mediation for environmental disputes. It has quickly built a creditable reputation among heretofore discordant groups by guiding the out-of-court resolution of such issues as neighbourhood zoning, air and water controls, and siting of public facilities.

A special project administered by the Institute and the Endowment is the Toxics Roundtable, a group of business, industry, and environmental, leaders who use the negotiation dialogue process to address problems of toxic substances and hazardous wastes. In its first year of monthly meetings, the Roundtable hammered out a comprehensive draft plan and recommendations for the State's hazardous-waste disposal facility regulations.

\section{Extensive Benefits of Grant Programmes}

The achievement demonstrated by these grant programmes goes far beyond the immediate benefits of environmental improvement. By transforming the usually tepid, sometimes volatile, atmosphere inhibiting relations between business and environmental groups, the Endowment is helping to create new opportunities for cooperative discussion, funding, and participation, to resolve the nation's most critical environmental dilemmas.

Almost two years ago, the Endowment was chosen to administer a \$1 million fund for water-quality programmes in an area outside of Virginia - the Ohio River Valley. The funds for this separate grant-making programme resulted from a federal water-pollution violation by the FMC Corporation. The Endowment is now meeting with officials from industry, government, environmental groups, and other foundations, to develop priorities and cooperative funding plans for waterquality protection in that region.

The Endowment is dedicated to serving as a catalyst in uniting human and scientific resources and encouraging people to work together to improve the environment. It is a model programme for developing good ideas into practical results on a regional scale, such as we hope may extend ultimately throughout the world.

GERALD P. MCCARTHY, Executive Director
Virginia Environmental Endowment
700 East Main Street
P.O. Box 790
Virginia 23206
USA.

\section{Wildlife Protection: Ensuring Observance Through the Council of Europe}

The illegal introduction of the American Rabbit Sylvilagus floridanus to Europe for hunting purposes threatens to destroy the delicate balance of wildlife on our continent*, according to Ambassador Alfred Wacker, Chairman of the new Standing Committee of the Wildlife Convention** and Permanent Representative of Switzerland to the Council of Europe. The Committee, set up under the Wildlife Convention to monitor its application, to ensure its adaptation to ecological evolution, and to intervene with Member States in the event of the Convention being contravened, held its first meeting at the end of September 1982 at the Council of Europe in Strasbourg. Other topical problems raised by the Committee were the precarious situation of migratory birds in periods of sudden cold (observed in par-

* The European Rabbit (Oryctolagus cuniculus) caused widespread damage and major problems in Australia following its introduction there in the last century.-Ed.

** See the account by E.J. Ausems of this 'Convention on the Conservation of European Wildlife and Natural Habitats' in Environmental Conservation, Vol. 7, No. 2, pp. 143-4, 1980.Ed. 
ticular during the winter of 1981-2), the introduction of hunting in certain protected areas, and the setting-up of tourist facilities in areas of great ecological value.

The Convention on the Conservation of European Wildlife and Natural Habitats has been signed by 20 Council of Europe countries and the EEC, and entered into force on 1 June 1982. It aims at the protection of wildlife in Europe as a whole, and of threatened species in particular. It is clear that the Convention can be instrumental in protecting wildlife if its application is assured by an independent authority. This is the purpose of the new Committee.

COUNCIL OF EUROPE B.P. $431 R 6$ F-67006 Strasbourg France.

\section{Military Activities and the Human Environment}

The Stockholm International Peace Research Institute (SIPRI) has entered into an agreement with the United Nations Environment Programme (UNEP), as of 1 February 1983 , for SIPRI to implement a jointly-financed six-years' project on 'Military Activities and the Human Environment'. The purpose of this project is to study, in a comprehensive way, the global impact on the human environment of the world's military sector in war (conventional, chemical, nuclear, etc.) as well as in peace. It is to address both the direct disruption of ecosystems, whether incidental or intentional, and the utilization of natural resources (raw materials) for military purposes. Conversely, it is expected as well to consider the influence of the human environment and its natural resources on military activities and international security in general. This set of studies will therefore fulfil the requirements of Chapter 15 of the United Nations System-wide Medium-term Environmental Programme, entitled 'The Arms Race and the Environment' (cf. UNEP/GC.10/7; 25 March 1982).

SIPRI is an independent institute for research into problems of peace and conflict - especially those of disarmament and arms regulation. An underlying purpose of SIPRI is to prevent or mitigate the pernicious effects of military activities. It was established in 1966 by the Swedish parliament (and is financed by it) to commemorate Sweden's 150 years of unbroken peace. UNEP, which has its headquarters in Nairobi, was established in 1972 by the United Nations General Assembly upon the recommendation of the United Nations Conference on the Human Environment, which had been held earlier that year in Stockholm. UNEP is the primary environmental planning and coordinating agency within the United Nations system, and also serves as the focal point for global environmental concerns.*

The project is being carried out under the direction of Dr Arthur H. Westing, Senior Research Fellow at SIPRI and Adjunct Professor of Ecology at Hampshire College, Amherst, Massachusetts, USA, who has had training and experience both as an artillery officer and as a forest ecologist, and who has had a long-time interest in the

* See, for example, our extensive featuring of UNEP in our Spring issue of last year.--Ed. ecological impact of warfare.** He is the Author of numerous articles on the subject + , and SIPRI has published three of his books in the field: Ecological Consequences of the Second Indochina War (1976), Weapons of Mass Destruction and the Environment (1977), and Warfare in a Fragile World: Military Impact on the Human Environment (1980). Dr Westing has offered relevant courses at Hampshire College, of which he was Dean of the School of Science, and during recent years has been a frequent consultant on the subject to UNEP.

SIPRI's research approach will be to identify the existing gaps in our knowledge of the interaction between military activities and the human environment. It will then either act to fill them with its own research staff or else commission the work to appropriate international and other research institutions or to qualified outside research workers. The primary product of these researches is to be a series of scholarly volumes published by SIPRI. A secondary product is to be a series of materials in a variety of written and audio-visual media for purposes of public information and education. These materials should provide an input to UNEP's contribution to the United Nations system-wide World Disarmament Campaign (cf. A/37/548; 3 Nov. 1982).

Among SIPRI's initial in-house studies are investigations into the impact on the human environment of the material remnants of war (such as the residue of hidden unexploded mines and other munitions), into the longterm effects on Man and Nature of the use of herbicides for hostile purposes, and into the environmental aftermath of the employment of lethal chemical weapons (the last by $\mathrm{Mr}$ Julian P. Perry Robinson). Other investigations and activities that are expected to be carried out in due course by SIPRI's own long-term research staff include studies of the military disruption of the upper atmosphere and of outer space (by Dr Bhupendra Jasani); of treaty and other legal considerations regarding the military impact on the human environment (by $\mathrm{Mr}$ Jozef Goldblat); and of approaches to public information and education (by Dr Malvern Lumsden). Other studies that are being contemplated include an analysis of the potential for manipulating the forces of Nature (meteorological, geological, and oceanographic) for hostile purposes, so-called geophysical warfare, and an examination of the question of whether there are ecologically important areas in the world where destruction would be particularly disruptive to the wider or even global environment - that is, to The Biosphere in major part or whole.

SIPRI expects to prepare a basis for coordination of the projects related to military activities and the human environment by other intergovernmental and nongovernmental agencies such as the United Nations Department of Disarmament Affairs (New York), United Nations Institute for Disarmament Research (Geneva), United Nations Educational, Scientific, and Cultural Organization (Paris), United Nations University (Tokyo), United Nations University for Peace (San José), Interna-

** In which connection we first ran across Dr Westing more than a decade ago, and published his 'Herbicides in War: Current Status and Future Doubt' in our old Journal (Biological Conservation, 4(5), pp. 322-7, figs, 1972.--Ed.

$\dagger$ Including several which we have been privileged to publish, such as his 'Environmental Impact of Nuclear War' (Environmental Conservation, 8(4), pp. 269-73, 1981), his Guest Editorial 'Environmental Consequences of Nuclear Warfare' (Ibid., 9(4), pp. 269-72, 1982), and the joint 'The Environmental Imperative of Nuclear Disarmament' heading up our present issue.-Ed. 